ORIGINAL ARTICLE

\title{
Fortified and freeze-dried kiwi fruit (Actinidia deliciosa): quality and sensory assessment
}

\section{Fruto do kiwi (Actinidia deliciosa) fortificado e liofilizado: avaliação sensorial e da qualidade}

\author{
Niladri Chakraborty', Rajat Chakraborty², Asit Kumar Saha1* (D) \\ ${ }^{1}$ Haldia Institute of Technology, Department of Food Technology, Haldia - West Bengal/India \\ 2Jadavpur University, Department of Chemical Engineering, Kolkata - West Bengal/India
}

*Corresponding Author: Asit Kumar Saha, Haldia Institute of Technology, P.O. - HIT campus, Purba Medinipur,

Pin code: 721657, Haldia - West Bengal/India, e-mail: principal.hit@hithaldia.in

Cite as: Chakraborty, N., Chakraborty, R., \& Saha, A. K. (2020). Fortified and freeze-dried kiwi fruit (Actinidia deliciosa): quality and sensory assessment. Brazilian Journal of Food Technology, 23, e2019077. https://doi.org/10.1590/1981-6723.07719

\begin{abstract}
Kiwi fruit (Actinidia deliciosa) (KF) is one of the best fruits available due to its large amount of nutrients. Despite its many health benefits, there are no previous reports on its preparation in other readily ingestible forms. The objective of the present study was to make a new food product from KF. The KF pulp was fortified and blended with several raw materials (such as rice flour and oat flour) using a stepwise short time addition and mixing methodology since this avoids unwanted biochemical and chemical reactions. The blended and reduced moisture KF paste was freeze-dried on a round silver coated steel plate (RSCSP), supplying the heat of sublimation using a newly designed cubic heater. The freeze-drying (FD) time was $4.5 \mathrm{~h}$ and the drying kinetics were studied using four established models. The effective moisture diffusivity ( $D_{\text {eff }}$ ) during FD (at $50^{\circ} \mathrm{C}$ ) was $1.532 \times 10^{-6} \mathrm{~m}^{2} / \mathrm{s}$ and the activation energy (E) estimated for the FD was $28.35 \mathrm{~kJ} / \mathrm{mol}$. The freeze-dried sample was ground and placed under vacuum to reduce the weathering effects. The quality of the stored product was evaluated using the proximate analysis, physicochemical analysis and a sensory evaluation using a hedonic scale. The raw, fresh KF had a moisture content of $85.07 \%$ and the final freeze-dried product one of $3 \%$. The carbohydrate, total sugar, protein, fat, total ash, crude fibre and vitamin C contents of the final product increased by $563 \%, 400 \%, 355 \%$, $386 \%, 672 \%, 106 \%$, and $117 \%$ respectively. Of the 66 panelists, the \% consumer acceptances for the different attributes were: sweetness $(68.18 \%)$, sourness $(90.91 \%)$, saltiness $(100 \%)$, bitterness $(100 \%)$, flavour $(95.45 \%)$, texture (77.27\%) and overall acceptability (81.82\%). Using conventional freeze-drying (CFD) for blended KF pulp without fortification, with the same RSCSP and the same cubic heater for sublimation, the drying time was found to be $7 \mathrm{~h}$ to reach the same final moisture content of $3 \%$.
\end{abstract}

Keywords: Fortified; Blended; Freeze-drying; Analysis; Hedonic scale; Drying time. 


\section{Resumo}

O fruto do kiwi (Actinidia deliciosa) (KF) é um dos melhores frutos disponíveis devido às quantias altas de nutrientes presentes. Apesar dos muitos benefícios a saúde, não há relatos anteriores sobre seu preparo em outras formas facilmente ingeríveis. O objetivo do presente estudo foi preparar um produto alimentício novo de KF. A polpa de $\mathrm{KF}$ foi fortificada e homogeneizada com várias outras matérias-primas cruas, tais como farinha de arroz e farinha de aveia, usando uma metodologia de adição e mistura de passo a passo e tempos curtos, para evitar reações bioquímicas e químicas indesejáveis. A pasta de KF homogeneizada e de baixa umidade foi liofilizada sobre uma placa redonda de aço revestida com prata (RSCSP), fornecendo o calor para a sublimação com um aquecedor cúbico de desenho recente. $O$ tempo de liofilização foi de 4,5 horas e a cinética da secagem foi estudada por meio de quatro modelos estabelecidos. A difusividade efetiva de umidade ( $D_{\text {eff }}$ ) durante a liofilização (a $50{ }^{\circ} \mathrm{C}$ ) foi de $1,532 \times 10^{-6} \mathrm{~m}^{2} / \mathrm{s}$ e a energia de ativação (E) estimada foi de $28,35 \mathrm{~kJ} / \mathrm{mol}$. A amostra liofilizada foi triturada e colocada sob vácuo para reduzir os efeitos ambientais. A qualidade do produto estocado foi avaliada pela sua composição centesimal, análises físico-químicas e uma avaliação sensorial usando uma escala hedônica. O KF fresco e cru possuía uma umidade de $85,07 \%$ e o produto liofilizado possuía uma umidade de $3 \%$. Os conteúdos de carboidrato, açúcar total, proteína, gordura, cinzas totais, fibra crua e vitamina $\mathrm{C}$ do produto liofilizado aumentaram em 563\%, 400\%, 355\%, 386\%, 672\%, 106\% e 117\%, respectivamente. Entre os 66 membros do painel, as porcentagens de aceitação do consumidor para os atributos diferentes foram: doçura (68,18\%), azedo (90,91\%), salgado (100\%), amargo (100\%), sabor (95,45\%), textura (77,27\%) e aceitação global (81,82\%). Usando liofilização convencional para a polpa homogeneizada de kiwi sem fortificação, com o mesmo RSCSP e o mesmo aquecedor cúbico para a sublimação, o tempo de secagem foi de $7 \mathrm{~h}$ para alcançar o mesmo teor de umidade de $3 \%$.

Palavras-chave: Fortificada; Homogeneizada; Liofilizada; Análise; Escala hedônica; Tempo de secagem.

\section{Introduction}

Kiwi fruit (Actinidia deliciosa) is known for its health-benefit properties such as low calorific value, low glycaemic index (GI), more vitamins (particularly vitamin C), high potassium content, high dietary fibre content, presence of a variety of pigments (such as chlorophylls, carotenoids, lutein, and anthocyanin), presence of a few important enzymes (such as proteases), low allergic response (AR) and finally its richness in natural antioxidants, polyphenols (Singletary, 2012). Its tiny seeds are distributed throughout the whole of the fruit pulp and have their own importance for consumption (Singletary, 2012; Parameswaran \& Murthi, 2014). Thus, it is better to process the fruit without separating the seeds.

Kiwi fruit $(\mathrm{KF})$ has a high moisture content $(>80 \%)$ and is classified as a highly perishable commodity (Orsat et al., 2006; Chin et al., 2015). Thus, it is a challenging task to maintain the product fresh since it gradually loses its freshness after a few days. To maintain the nutritional value of the fruit intact, most preservation/storage techniques require low temperatures, which are very difficult to maintain throughout the supply chain distribution system (Sagar \& Suresh Kumar, 2010). Moreover, the vitamin C content of the fruit decreases with time during low-temperature preservation (Tavarini et al., 2008). These negative effects could be overcome by using advanced drying techniques such as freeze-drying (Bezyma \& Kutovoy, 2006). Freeze-drying is a process carried out at sub-zero temperatures where the ice sublimes to reduce the water activity. It leads to a decrease in the rates of all the degradative processes such as non-enzymatic browning, protein deterioration and enzymatic reactions (Salunkhe et al., 1991). However, the cost involved is prohibitively high due to the long drying time. To reduce the drying time and hence the preservation costs, a new drying methodology, successive osmotic dehydration, and freeze-drying (ODFD) was investigated and reported earlier (Chakraborty et al., 2016).

Freeze-drying (FD) can be applied to both solid and liquid product forms (Food Safety and Standards Authority of India, 2010). The highly valued product instant coffee is a classic example of FD in the liquid form (Burmester et al., 2011). Modern food processing improves the quality of human life and decreases the 
possibility of diabetes, heart disease, cancers and the like (Food Safety and Standards Authority of India, 2010). Food additives are substances that improve the quality, nutritive value, processing parameters, and shelf life, and maintain the palatability, wholesomeness and product consistency (Food Safety and Standards Authority of India, 2010). Therefore, the addition or fortification of KF pulp with the proper additives could improve cost-effectiveness as well as the nutritional value of the product. The additives were divided into two types according to the portion size viz. larger portions and smaller portions and were selected for KF processing. Of the larger portion additives, rice flour and oat flour were chosen. Rice flour contains complex carbohydrates, no gluten (which favours non-stickiness of the final product), and almost no protein or fat. It acts as a thickening agent, soft texture improver and flavour enhancer (Duncan, 2000). The oat flour complements the deficiencies by providing high energy ( $380 \mathrm{kcal}$ per $100 \mathrm{~g})$, high protein $(12 \mathrm{~g}$ per $100 \mathrm{~g})$ and high dietary fibre ( $10 \mathrm{~g}$ per $100 \mathrm{~g}$ ) contents. Dietary fibre consists of cellulose, hemicellulose, lignin and peptic substances and plays an important role in relieving constipation by increasing the water holding capacity. Its consumption is also linked to a reduction in the appetite, a decreased variance in the blood sugar levels, and decreased incidence of cardiovascular disease (since it lowers the total and LDL cholesterol) and of colon cancer (Dhingra et al., 2012). Of the smaller portion additives granulated sugar, salt (blends of iodized and low Na salt in a 1:1 ratio), calcium lactate and trace amounts of sodium benzoate, are used. The sugar and salt act as both preservatives and taste enhancers of the final product. In fact, the sugar is used to prevent browning of the peeled and sliced fruit, inhibiting oxidation by partially excluding air from the tissues. In KF, the dry sugar powder is mixed with the pulp, and since KF is rich in ascorbic acid and citric acid, the addition of sugar to the KF acts as an effective agent against the losses of texture, colour, and flavour (Barrett et al., 2005). Lona (low Na) salt is used since it is low in sodium and rich in potassium (Na 23\%, K $38 \%$ ). The most common treatment used to improve texture retention, prevent decay, sanitise the product and enrich the nutritional value of the fresh fruits is that of adding different calcium salts (such as calcium lactate - maximum 1\% w/w) (Martin-Diana et al., 2007). The calcium lactate treatment of the samples prolongs the shelf-life and tends to maintain greater firmness during storage (Benitez et al., 2014). It serves as a firming salt for fruits and acts as a gelling agent, particularly for KF-like fruits. Sodium benzoate is a chemical preservative, which can play a very important role in fruit processing and is most effective in the $\mathrm{pH}$ range from 2.5 to 4 (Barrett et al., 2005). KF contains mainly citric, malic and quinic acids and during ripening, its $\mathrm{pH}$ value varies from 3.1 to 3.96 such that it is classified as a 'high acid' food. According to the IOMC (Inter-Organization Programme for the Sound Management of Chemicals), $0.01 \%$ (solution in water, w/w) sodium benzoate (EU No. 211) is the maximum concentration that can be added to fruit items and can, therefore, be added to KF. Sodium benzoate is less effective against bacteria and more active against yeasts and moulds. Since the maximum recommended dose by the IOMC is only $0.01 \%$, its activity will be poor above $\mathrm{pH} 4$ where bacteria are the greatest problem (Barrett et al., 2005).

In the present research, KF pulp was converted to KF-paste by the addition of a few natural domestic ingredients, using a trial and error method to determine the amounts necessary to reduce the initial moisture content of the KF pulp and also increase the quality of the product. Finally, the KF-paste was freeze-dried using a six-sided cubic heater (made of pure stainless steel) for sublimation to reach a final moisture level of $<5 \%$. Before freezing, the KF-paste was maintained on a round silver coated steel plate, RSCSP. The kinetic parameters during FD were studied. Finally, the product was ground and placed under vacuum to reduce the weathering effects and then stored to carry out the proximate analysis. Moreover, several physicochemical and organoleptic properties of the final KF powder were investigated. In addition, a conventional FD (CFD) technique was used to dry blended KF pulp without fortification and maintained on the same RSCSP for FD. 


\section{Material and methods}

\subsection{Sample preparation for freeze-drying}

Fresh kiwi fruits (Actinidia deliciosa) were peeled and cut into small pieces using a sterilized stainless-steel knife. The moisture content of the sample was determined using a moisture metre (KERN, Germany, Model MLS 50-3 HA 250). A known weight of a sample of about $0.1 \mathrm{~kg}$, was placed in a blender (PHILIPS, model no. HL 1632, $230 \mathrm{~V}, \mathrm{AC}, 50 \mathrm{~Hz}, 500 \mathrm{~W}$ ) and blended at a moderate speed ( $\sim 400$ to $500 \mathrm{rpm}$ ) with the stepwise, serial addition of several ingredients. The selected ingredients were rice flour, oat flour, ground sugar, salt (iodized and low $\mathrm{Na}$ in a 1:1 ratio), calcium lactate and a pinch of sodium benzoate as the preservative. All the additives were added to the raw KF as per Table 1.

Table 1. The weights of rice flour, oat flour, ground sugar, low Na salt, calcium lactate and sodium benzoate added to the kiwi fruit $(\mathrm{KF})$ to prepare the blended kiwi fruit (BKF) samples.

\begin{tabular}{|c|c|c|c|c|c|c|c|}
\hline $\begin{array}{c}\text { Raw } \\
\text { KF } \\
{[\mathbf{k g}]}\end{array}$ & $\begin{array}{c}\text { Rice flour } \\
(1 \%, w / w) \\
{[\mathbf{k g}]}\end{array}$ & $\begin{array}{c}\text { Oat flour } \\
(1 \%, w / w) \\
{[\mathrm{kg}]}\end{array}$ & $\begin{array}{c}\text { Ground } \\
\text { sugar } \\
(0.5 \%, \text { w/w) } \\
{[\mathrm{kg}]} \\
\end{array}$ & $\begin{array}{c}\text { Low Na salt } \\
(0.5 \%, \mathrm{w} / \mathrm{w}) \\
{[\mathrm{kg}]}\end{array}$ & $\begin{array}{c}\text { Calcium } \\
\text { lactate } \\
(1 \%, w / w) \\
{[\mathrm{kg}]} \\
\end{array}$ & $\begin{array}{c}\text { Sodium } \\
\text { benzoate } \\
(0.02 \%, w / w) \\
{[\mathrm{kg}]} \\
\end{array}$ & $\begin{array}{c}\text { Prepared } \\
\text { blended KF } \\
\text { (BKF) } \\
{[\mathrm{kg}]} \\
\end{array}$ \\
\hline 0.1 & 0.001 & 0.001 & 0.0005 & 0.0005 & 0.001 & 0.00002 & 0.10402 \\
\hline
\end{tabular}

The total blending time was maintained between 25 to $30 \mathrm{~s}$ and hence the average blending time for each ingredient was limited to 4 to $5 \mathrm{~s}$. Excessive blending (both in time and rpm) was avoided to prevent unwanted biochemical and chemical reactions which would increase the sourness and bitterness of the stock solution. The fortified and blended kiwi-paste, known as 'blended kiwi fruit' (BKF), was removed from the blender and its moisture content determined.

Finally, the BKF was weighed (approx. $0.03 \mathrm{~kg}$ per batch), placed on the RSCSP (diameter $82 \mathrm{~mm}$, thickness $0.5 \mathrm{~mm}$, depth $6 \mathrm{~mm}$ ) and spread uniformly (depth of about $5 \mathrm{~mm}$ ) on the inside area of the RSCSP for freezing. The BKF sample was frozen in a conventional freezer for 18 hours at $-18{ }^{\circ} \mathrm{C}$ and then freeze-dried. The same technique was used to prepare KF pulp without fortification and spread on the same RSCSP for freezing in the same freezer for 18 hours at $-18^{\circ} \mathrm{C}$ followed by freeze-drying.

\subsection{Experimental methodology for freeze-drying}

For freeze-drying, the same freeze dryer described in a previous paper by the same authors (Chakraborty et al., 2016) was used, together with a new six-sided cubic heating chamber (dimensions: $90 \times 90 \times 90 \mathrm{~mm}$; working conditions: $220 \mathrm{~V}, 166 \mathrm{~mA}, 33 \mathrm{~W}$ ) designed by the authors. By using the cubic heating chamber, the heat was supplied from the four side walls as well as from the bottom surface. The top of the chamber was open to allow the sublimed vapours to escape from the sample. The frozen sample, together with the RSCSP were placed inside the cubic heating chamber, which was placed inside the freeze dryer. The freeze dryer was maintained under a constant vacuum of $5 \times 10^{-3} \mathrm{mbar}$ and the condenser (moisture trap) at $-40{ }^{\circ} \mathrm{C}$. A PID controller equipped with a resistance temperature detector (RTD, Pt-100) was used to monitor and control the temperature of the hot steel surface. Simultaneously, another RTD was inserted into the sample to record the temperature during drying. During freeze-drying, the weight of the frozen and dried BKF was measured and recorded at fixed time intervals. The time when the final moisture content of the sample reached $\leq 5 \%(\mathrm{w} / \mathrm{w})$ was also recorded. 


\subsection{Drying kinetics}

Different drying models, namely the Page, Wang \& Sing, Henderson \& Pebis and Newton models were tested to compare the drying kinetics during freeze-drying. The statistical parameters such as the mean bias error (MBE), the root mean square error (RMSE) and the modelling efficiency (EF) were calculated using the following equations:

$$
\begin{aligned}
& \mathrm{MBE}=\frac{1}{\mathrm{~N}} \sum_{\mathrm{i}=1}^{\mathrm{N}}\left(\mathrm{MR}_{\text {pre, } \mathrm{i}}-\mathrm{MR}_{\text {exp, } \mathrm{i}}\right) \\
& \operatorname{RMSE}=\left[\frac{1}{\mathrm{~N}} \sum_{\mathrm{i}=1}^{\mathrm{N}}\left(\mathrm{MR}_{\mathrm{pre}, \mathrm{i}}-\mathrm{MR}_{\mathrm{exp}, \mathrm{i}}\right)^{2}\right]^{0.5} \\
& \mathrm{EF}=\frac{\sum_{\mathrm{i}=1}^{\mathrm{N}}\left(\mathrm{MR}_{\text {exp }, \mathrm{i}}-\mathrm{MR}_{\text {exp,avge }}\right)^{2}-\sum_{\mathrm{i}=1}^{\mathrm{N}}\left(\mathrm{MR}_{\text {pre, } \mathrm{i}}-\mathrm{MR}_{\text {exp, } \mathrm{i}}\right)^{2}}{\sum_{\mathrm{i}=1}^{\mathrm{N}}\left(\mathrm{MR}_{\text {exp }, \mathrm{i}}-\mathrm{MR}_{\text {exp,avge }}\right)^{2}}
\end{aligned}
$$

For Equation 1, 2 and 3: $\mathrm{MR}_{\mathrm{pre}, \mathrm{i}}=$ predicted moisture ratio of $\mathrm{i}$-th count; $\mathrm{MR}_{\mathrm{exp}, \mathrm{i}}=$ experimental moisture ratio of $\mathrm{i}$-th observation; $\mathrm{MR}_{\text {exp, avrg }}=$ arithmetic average experimental moisture ratios; $\mathrm{N}=$ number of observations/counts.

The moisture ratio (MR) can be calculated using the following equation:

$\operatorname{MR}=\frac{M_{C}}{M_{O}}=\frac{\left[\left(W_{o}-W_{e}\right)-W_{d}\right] / W_{d}}{W_{i, w} / W_{d}}$

Where:

$M_{c}=$ the moisture content at a particular time with respect to the dry solids;

$M_{0}=$ the initial moisture content with respect to the dry solids;

$W_{o}=$ initial sample weight $(\mathrm{g})$;

$W_{e}=$ amount of water evaporated $(\mathrm{g})$;

$W_{d}=$ dry matter content of the sample $(\mathrm{g})$;

$W_{i, w}=$ initial weight of water in the sample $(\mathrm{g})$.

The unsteady-state diffusion equation used to calculate the effective diffusion coefficient ( $\mathrm{D}_{\text {eff }}$ ) was as follows (Chakraborty \& Roychowdhury, 2013):

$\mathrm{MR}=\frac{8}{\pi^{2}} \operatorname{Exp}\left[-\frac{\pi^{2} * \text { Deff } * \mathrm{t}}{4 \mathrm{~L}^{2}}\right]$

Where:

$t=$ the time in seconds;

$L=$ the thickness or depth of the sample in the RSCSP.

The activation energy (E) was calculated using the Arrhenius equation as follows:

$\ln \left(\frac{D_{\text {eff }, 2}}{D_{\text {eff }, 1}}\right)=\left(\frac{E}{R}\right)\left[\frac{\left(T_{2}-T_{1}\right)}{T_{1} * T_{2}}\right]$

Where:

$\mathrm{E}=$ activation energy, $\mathrm{kJ} / \mathrm{mol}$;

$\mathrm{R}=$ universal gas constant, $8.314 \mathrm{~kJ} /(\mathrm{mol} . \mathrm{K})$;

$\mathrm{T}_{1}$ and $\mathrm{T}_{2}=$ temperature (in $\mathrm{K}$ ) at two different observations 1 and 2 respectively. 
After freeze-drying, the blended freeze-dried KF (BFDKF) was ground (using the same grinder used before) with a short time span. The dried powder was put back into the vacuum dryer for about 30 minutes with the heater in the off position, and finally stored in an air-tight container for a quality assessment or for other purposes.

\subsection{Quality assessment}

The proximate analysis can be used as a yardstick for the quality assessment of food products. It is basically the partitioning of the samples into the following six categories: moisture content, ash content, crude protein content, crude lipids content, crude fibre content, and the carbohydrate content. The proximate analysis and physicochemical properties of the BFDKF powder were determined using standard analytical procedures.

\subsubsection{Moisture}

The moisture content of the final sample was determined using a moisture meter (KERN, Germany, Model MLS 50-3 HA 250).

\subsubsection{Ash}

$5 \mathrm{~g}$ of BFDKF powder was placed in a porcelain bowl, which was then placed inside a muffle furnace at 550 to $600{ }^{\circ} \mathrm{C}$ and incinerated until grey ash was obtained. This was then cooled in a desiccator and weighed. The process of heating, cooling and weighing was repeated at 30 minute-intervals until the difference in weight between two consecutive weights was $<1 \mathrm{mg}$. The lowest value for the total ash weight was recorded.

\subsubsection{Crude protein}

The crude protein content was determined from the organic nitrogen content, as determined by the Kjeldahl method. The various nitrogenous compounds were converted into ammonium sulphate by boiling with concentrated sulphuric acid. The ammonium sulphate formed was decomposed by a sodium hydroxide solution and the ammonia liberated absorbed in an excess of a standard acid solution and then back titrated using standard alkali.

\subsubsection{Crude lipids}

Twenty g of BFDKF powder was weighed accurately and transferred into an extraction thimble and plugged at the top with cotton wool and filter paper. The Soxhlet apparatus was fitted with a boiling flask using petroleum ether (boiling point 40 to $80^{\circ} \mathrm{C}$ ) as the extraction solvent. After 5 to 6 cycles, the solvent present in the flask (contained the fat) was evaporated on a water bath. The traces of residual solvent were removed by putting the flask in a hot air oven $\left(\right.$ at $\left.105^{\circ} \mathrm{C}\right)$ for about 30 minutes.

\subsubsection{Crude fibre}

The defatted BFDKF powder was transferred to a boiling flask containing dilute sulphuric acid $(1.25 \%, \mathrm{w} / \mathrm{v})$. The flask was connected to a water-cooled reflux condenser, some glass beads added to the flask to avoid unnecessary bumping, and the solution heated for 30 to 45 minutes. After boiling, the solution was filtered through Whatman filter paper, washed with boiling water until the washings were free from acid and the precipitate collected. The same procedure was followed using boiling dilute sodium hydroxide solution $(1.25 \%, \mathrm{w} / \mathrm{v})$. After 30 minutes, boiling was stopped and the solution washed and filtered until the washings were free from alkali. The final precipitate was dried at $105 \pm 2{ }^{\circ} \mathrm{C}$ in an oven to constant weight. The contents were cooled, weighed, incinerated in a muffle furnace until all carbonaceous matter was burnt, the ash was cooled and the final weight was taken. 


\subsubsection{Carbohydrates/Total sugars}

The titration method (Lane-Eynon) was used to determine the carbohydrates/total sugars (glucose, fructose). A burette was used to add the carbohydrate/sugar solution being analysed to a flask containing a known amount of boiling Fehling solutions (Fehling A: Fehling B:: 1:1) until any further addition of reducing sugars caused the indicator (methylene blue) to change from blue to red. The volume of sugar solution consumed to reach the endpoint was recorded. Since the reaction is not stoichiometric, a standard glucose solution was used to prepare a calibration curve with a series of standard solutions of known carbohydrate concentration.

\subsubsection{Titratable acidity}

Titratable acidity can be expressed in grams of acid per $100 \mathrm{~g}$ or per $100 \mathrm{ml}$ of the sample under test. In the present case, titratable acidity was measured in terms of malic acid $(1 \mathrm{ml}$ of $0.1 \mathrm{~N} \mathrm{NaOH}=0.0067 \mathrm{~g}$ of malic acid). A known weight of the sample was thoroughly diluted/mixed with distilled water $(\mathrm{pH}=7)$, filtered and the filtrate used as the stock solution. We transferred 2 to $3 \mathrm{ml}$ of stock solution to about $20 \mathrm{~mL}$ of neutral water in a beaker and titrated with $0.1(\mathrm{~N}) \mathrm{NaOH}$ to the endpoint using phenolphthalein as the indicator.

\subsubsection{Vitamin C}

Vitamin $\mathrm{C}$ was determined using the 2,6-dichlorophenol indophenol method. The BFDKF powder (about $5 \mathrm{~g}$ ) was thoroughly mixed with a $10 \%(\mathrm{w} / \mathrm{v})$ TCA (tricarboxylic acid) solution in a mortar until homogeneous. This mixture was transferred to a $100 \mathrm{ml}$ graduated flask, shaken thoroughly and the volume made up to $100 \mathrm{~mL}$ with the TCA solution. This solution was then filtered and $10 \mathrm{ml}$ of the filtrate titrated with standardized 2,6-dichlorophenol indophenol solution to the endpoint. A similar method was applied to the standard ascorbic acid solution (1 mg standard, USP, ascorbic acid per $1 \mathrm{~mL}$ TCA solution).

\subsubsection{Vitamin A}

The BFDKF powder (about $1 \mathrm{~g}$ ) was added to $5 \mathrm{ml}$ of methanol and allowed to rest for $2 \mathrm{~h}$ at room temperature $\left(27 \pm 2{ }^{\circ} \mathrm{C}\right)$ in the dark to complete the extraction. The $\beta$-carotene layer was separated using hexane in a separating funnel, the volume made up to $10 \mathrm{~mL}$ with hexane and the layer passed through sodium sulphonate in a funnel to remove moisture from the layer. The absorbance of the layer was measured at $436 \mathrm{~nm}$ using hexane as the blank (Ranganna, 1999).

\subsection{Sensory evaluation}

\subsubsection{Serving protocol}

The final BFDKF sample was kept in an airtight container and stored under refrigeration $\left(5\right.$ to $\left.8^{\circ} \mathrm{C}\right)$. It was served to the participants using the standard ASTM International (2017) methodology (E1871-17). Aliquots of $2 \mathrm{~g}$ of each sample (BFDKF) were placed in small clean stainless steel bowls and served to each participant. A small spoon and drinking water (maintained in food-grade plastic bottles) were placed near the bowl. The participants could test the sample as they chose after rinsing their mouths with drinking water.

\subsubsection{Evaluation process}

The sensory evaluation process was carried out as follows. The participants had no prior information about the product and none were involved in its development. They were given no information about the judgment of the others and no two-panel members were present at the same time and place (when he/she was judging the sample). This was done to avoid being influenced by the judgment of the others. 


\subsubsection{Sensory panel}

The sensory panel consisted of 66 participants/panelists (Joshi et al., 2016) representing the different educated and non-educated categories in a ratio of 8:3 and their responses were taken three times at different points in time.

The participants were asked to indicate their preferences on a 9-point hedonic scale, which has proven itself to be a simple and effective measuring device, suitable for use by a wide range of populations without extensive training (Lim, 2011). The scoring was as follows: $9=$ like extremely, $8=$ like very much, $7=$ like moderately, $6=$ like slightly, $5=$ neither like or dislike, $4=$ dislike slightly, $3=$ dislike moderately, $2=$ dislike very much and $1=$ dislike extremely. They were asked to score the BFDKF powder with respect to the following parameters: sweetness, sourness, saltiness, bitterness, Flavour, Texture (gummy or powdery nature) and overall acceptability. The percentage (\%) of consumer acceptance was calculated using the following equation (Jayasena \& Cameron, 2008):

$\%$ consumer acceptance $=\frac{\text { Number of panellists rating }>5}{\text { Total number of panellists }} \times 100$

The average score and total score can be calculated using the following two equations (Singh-Ackbarali \& Maharaj, 2014):

Average score $=\frac{\text { Total points for individual parameters }}{\text { Total number of panellists }}$
Total score $=\frac{\text { Total points for individual parameters }}{(\text { Total number of panellists })(\text { Maximum hedonic points })} \times 100$

\section{Results and discussion}

\subsection{Moisture analysis}

The moisture contents of the raw \& fresh KF, BKF and the BFDKF powder were determined to be $85 \%$, $68 \%$ and $3 \%(p<5 \%)$ respectively on a wet basis.

\subsection{Drying kinetics of fortified, blended and frozen sample}

The fortified, blended and frozen kiwi sample was freeze-dried and its drying kinetics studied.

\subsubsection{Mathematical models}

The drying kinetics of the frozen BKF sample was investigated using four mathematical models (Table 2).

Table 2. Mathematical models investigated.

\begin{tabular}{|c|c|c|}
\hline Serial no. & Model name & Equation used \\
\hline 1. & Page & $\mathrm{MR}=\exp \left(-k \mathrm{t}^{\mathrm{n}}\right)$ \\
\hline 2. & Wang \& Sing & $\mathrm{MR}=1+\mathrm{at}+\mathrm{bt}^{2}$ \\
\hline 3. & Henderson \& Pabis & $M R=a \exp (-k t)$ \\
\hline 4. & Newton & $\mathrm{MR}=\exp (-\mathrm{kt})$ \\
\hline
\end{tabular}

$\overline{\mathrm{MR}}=$ moisture ratio.

\subsubsection{Statistical analysis of the FD models}

The constants for the different models $(\mathrm{k}, \mathrm{a}, \mathrm{b}, \mathrm{n})$ were calculated using the MR values (Equation 4) and the equations from Table 2. The values for the regression coefficients $\left(\mathrm{R}^{2}\right)$ (using Microsoft Excel), mean bias errors (MBE), root mean square errors (RMSE) and modelling efficiency (EF) were calculated using 
Equations 1, 2 and 3, respectively for the freeze-dried (FD) models and SCSRP for BKF in order to find the best fitting/accepted model of the four models, as presented in Table 3.

Table 3. Freeze drying model constants and statistical parameters for the blended kiwi fruit (BKF) samples.

\begin{tabular}{ccccccccc}
\hline Model & $\mathbf{k}$ & $\mathbf{a}$ & $\mathbf{b}$ & $\mathbf{n}$ & $\mathbf{R}^{\mathbf{2}}$ & $\mathbf{E F}$ & $\mathbf{M B E}$ & $\mathbf{R M S E}$ \\
\hline Page & 0.02 & - & - & 0.95 & 0.963 & 0.84243 & 0.00453 & 0.12605 \\
\hline Wang \& Sing & - & -0.044 & 0.00028 & - & 0.926 & -4.6046 & -0.69806 & 0.75175 \\
\hline Henderson \& Pabis & 0.0112 & 1.002 & - & - & 0.985 & 0.66665 & 0.11047 & 0.18334 \\
\hline Newton & 0.0155 & - & - & - & 0.973 & 0.84525 & 0.02348 & 0.12492 \\
\hline
\end{tabular}

The predicted regression coefficients $\left(\mathrm{R}^{2}\right.$ pred $)$ for all four models were compared with the experimental values $\left(\mathrm{R}_{\exp }^{2}=0.9902\right)$ as shown in Table 4 .

Table 4. Comparison of the regression coefficients $\left(\mathrm{R}^{2}\right)$ with the experimental regression coefficients $\left(\mathrm{R}^{2} \exp \right)$ for the four models.

\begin{tabular}{|c|c|c|c|c|}
\hline Model & $\begin{array}{l}\text { Predicted Regression } \\
\text { coefficient }\left(\mathbf{R}^{2} \text { pred }\right)\end{array}$ & $\begin{array}{c}\text { Experimental } \\
\text { Regression coefficient } \\
\left(\mathbf{R}^{2}{ }_{\text {exp }}\right)\end{array}$ & $\begin{array}{c}\text { Difference } \\
\left(\mathbf{R}^{2}{ }_{\exp }-\mathbf{R}^{2} \text { pred }\right)\end{array}$ & Deviation (\%) \\
\hline Page & 0.9634 & 0.9902 & 0.0268 & 2.7065 \\
\hline Wang \& Sing & 0.9261 & 0.9902 & 0.0641 & 6.4734 \\
\hline Henderson \& Pabis & 0.9854 & 0.9902 & 0.0048 & 0.4847 \\
\hline Newton & 0.9726 & 0.9902 & 0.0176 & 1.7774 \\
\hline
\end{tabular}

The $\mathrm{R}^{2}$ pred values did not deviate much from the $\mathrm{R}^{2}$ exp values except for the Wang \& Sing model. This means that the experimental error was small. The highest $R^{2}$ and $E F$ values were better for the accepted drying model. Simultaneously, the lowest MBE and RMSE values were better for the accepted drying model. What is more, the RMSE was more appropriate for use than the MBE when the model errors followed a normal distribution (Chai \& Draxler, 2014). Table 3 shows that the RMSE value was smallest (0.12492) for the Newton model, closely followed by the Page model (RMSE $=0.12605)$.

Bearing in mind all the considerations, the Newton model was accepted as the best drying model for the FD of frozen BKF as compared with the other models. Figure 1 shows the comparison of the regression coefficient $\left(\mathrm{R}^{2}\right)$ for the experimental value $\left(\mathrm{R}^{2} \exp =0.9902\right)$ with that of the Newton model (which was $\left.\mathrm{R}_{\text {pred }}^{2}=0.9726 \approx 0.973\right)$.

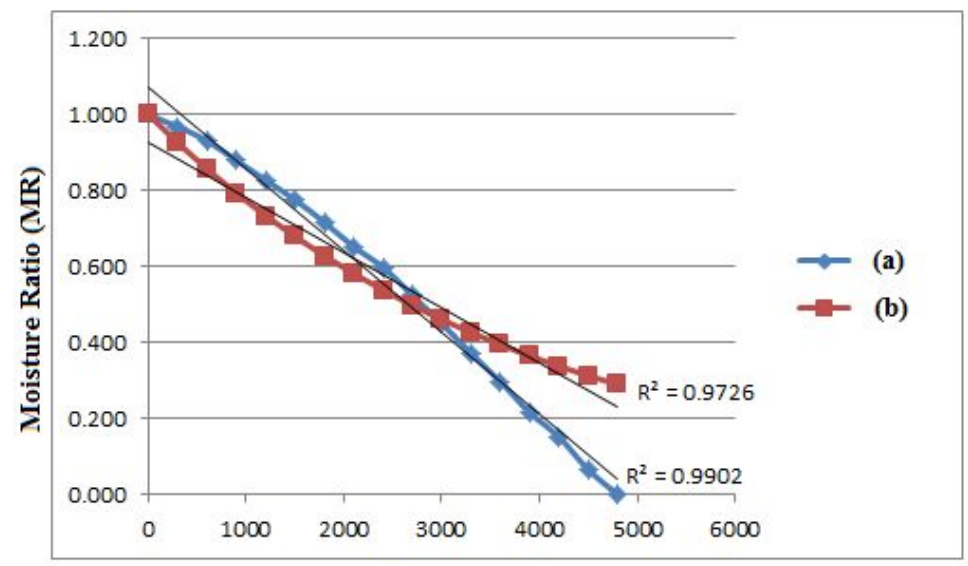

Time (in seconds)

Figure 1. Graph of the moisture ratio (MR) versus time to compare the regression coefficients $\left(\mathrm{R}^{2}\right)$ for (a) the experimental value $\left(\mathrm{R}_{\exp }^{2}=0.9902\right)$ and $(\mathrm{b})$ the Newton model $\left(\mathrm{R}_{\mathrm{pred}}^{2}=0.9726\right)$. 
In Figure 2, the true (experimental) and predicted values for the moisture ratio (MR) were compared for all four models. It was found that the curve for the Wang \& Sing model was far from the experimental curve, but the curves for the other models, namely the Page, Henderson \& Pabis and Newton models, were close to the experimental curve.

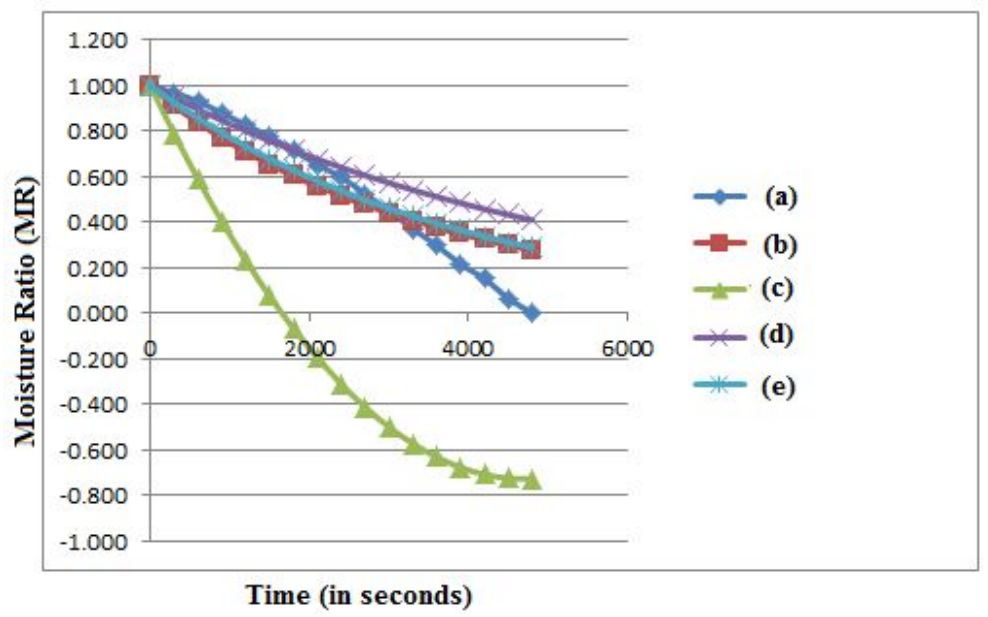

Figure 2. Freeze drying curves for the BKF sample: (a) Experimental value (b) Page model (c) Wang \& Sing model (d) Henderson \& Pebis model (e) Newton model.

\subsection{Freeze-drying performance using a cubic steel heater}

The effective moisture diffusivity ( $\mathrm{D}_{\text {eff }}$ ) for the freeze-dried BKF and CFD for kiwi pulp (without added ingredients or fortification) were obtained using Equation 5. The values for $\mathrm{D}_{\text {eff }}$ were calculated at different temperatures $\left(40^{\circ}, 45^{\circ}\right.$ and $\left.50^{\circ} \mathrm{C}\right)$ for both the samples and presented in Tables 5 and 6 .

Table 5. Effective moisture diffusivity $\left(\mathrm{D}_{\text {eff }}\right)$ and activation energy $(\mathrm{E})$ for the freeze-drying of blended kiwi fruit (BKF) using the cubic steel heater.

\begin{tabular}{ccc}
\hline $\begin{array}{c}\text { Temperature } \\
\left({ }^{\circ} \mathbf{C}\right)\end{array}$ & $\begin{array}{c}\text { Deff for the FD of BKF } \\
\left(\mathbf{m}^{2} / \mathbf{s}\right)\end{array}$ & $\begin{array}{c}\text { Activation energy required for the } \\
\text { FD of BKF }(\mathbf{k J} / \mathbf{m o l})\end{array}$ \\
\cline { 1 - 2 } 40 & $1.892 \times 10^{-7}$ & \\
\hline 45 & $5.366 \times 10^{-7}$ & 28.35 \\
\hline 50 & $1.532 \times 10^{-6}$ & \\
\hline
\end{tabular}

Table 6. Effective moisture diffusivity ( $\mathrm{D}_{\text {eff }}$ ) and activation energy (E) for the CFD of kiwi fruit pulp (without the addition of ingredients) using the same cubic steel heater.

\begin{tabular}{|c|c|c|}
\hline Temperature $\left({ }^{\circ} \mathrm{C}\right)$ & $D_{\text {eff }}$ for the CFD of KF pulp $\left(\mathrm{m}^{2} / \mathrm{s}\right)$ & $\begin{array}{c}\text { Activation Energy (E) required for } \\
\text { the CFD of KF }(\mathrm{kJ} / \mathrm{mol})\end{array}$ \\
\hline 40 & $1.012 \times 10^{-9}$ & \multirow{3}{*}{44.12} \\
\hline 45 & $3.958 \times 10^{-9}$ & \\
\hline 50 & $2.651 \times 10^{-8}$ & \\
\hline
\end{tabular}

At $50{ }^{\circ} \mathrm{C}$ (material temperature), the value of the effective moisture diffusivity ( $\mathrm{D}_{\text {eff }}$ ) was-found to be $1.532 \times 10^{-6} \mathrm{~m}^{2} / \mathrm{s}$ for the FD of BKF (Table 5) and $2.651 \times 10^{-8} \mathrm{~m}^{2} / \mathrm{s}$ for the CFD of kiwi pulp alone (Table 6). The data clearly show that the $D_{\text {eff }}$ was lower for the CFD of kiwi fruit than for the FD of BKF at all temperatures of the experiment. The drying time required to attain a final moisture content of $3 \%$ for the sample of BFDKF was $4.5 \mathrm{~h}$.

Using Equation 6 a graph of $\ln \left(\mathrm{D}_{\text {eff }}\right)$ versus $1 / \mathrm{T}$ was plotted for both samples as shown in Figures 3 and 4. 


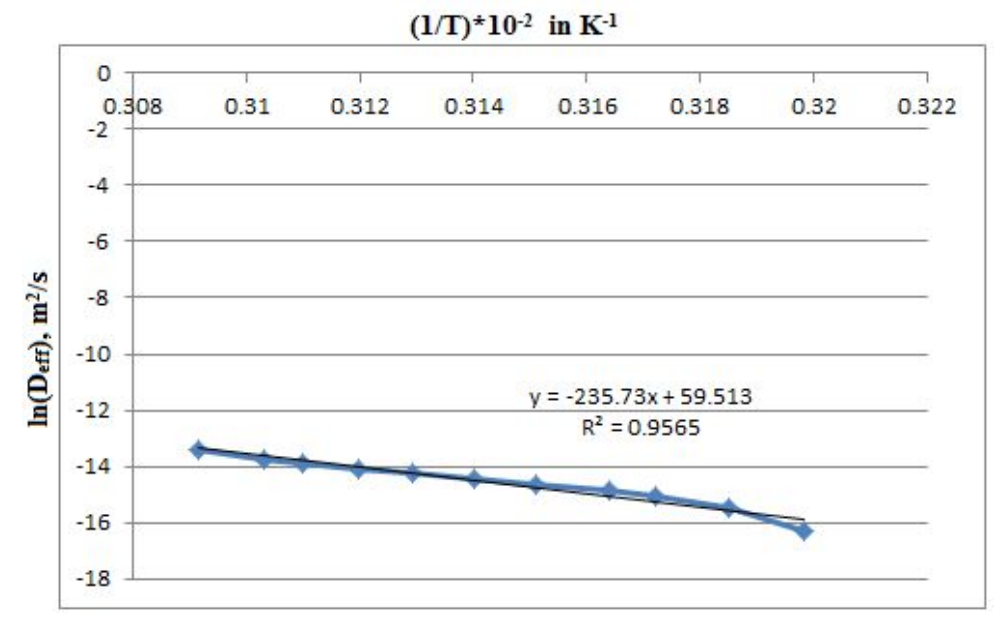

Figure 3. The graph of $\ln \left(\mathrm{D}_{\text {eff }}\right)$ versus $(1 / \mathrm{T})$ for the freeze-drying of BKF to determine the activation energy $(\mathrm{E})$.

The value for $\mathrm{R}^{2}$ of the line was 0.9565 , which is a satisfactory value for the fit. Hence, the activation energy (E) required during the FD of the frozen BKF sample was found to be $28.35 \mathrm{~kJ} / \mathrm{mol}$ (Table 5) using the equation obtained $(y=-235.73 x+59.513)$ from the graph (Figure 3$)$.

Using the same RSCSP and cubic heater for CFD, the drying time was found to be $7 \mathrm{~h}$ to reach the same final moisture content of $3 \%$ for blended KF pulp alone (without added ingredients or fortification). This means that with the fortification of the KF pulp (with rice, oat flour, etc.), the FD time was reduced by $35 \%$ as compared to CFD.

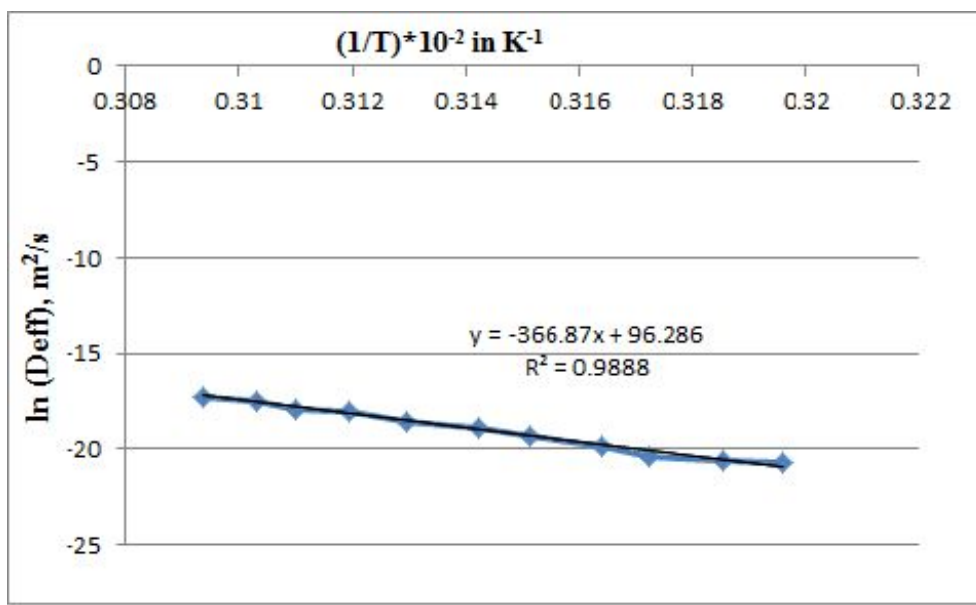

Figure 4. The graph of $\ln \left(\mathrm{D}_{\text {eff }}\right)$ versus $(1 / \mathrm{T})$ for the CFD of blended kiwi pulp alone (without added ingredients or fortification of the kiwi pulp) to determine the activation energy (E).

The $\mathrm{R}^{2}$ value of the line was 0.9888 , which is a satisfactory value for the fit. Hence, the activation energy (E) required during the FD of the frozen BKF sample was found to be $44.12 \mathrm{~kJ} / \mathrm{mol}$ (Table 6) using the equation developed $(y=-366.87 \mathrm{x}+96.286)$ from the graph (Figure 4). Therefore, the CFD of BKF alone had a higher E-value than the FD of BKF; which signifies that the drying time of CFD (7 h) was higher than that of the FD of the BKF sample $(4.5 \mathrm{~h})$. 


\subsection{Quality assessment of the Kiwi Fruit (KF) and Blended Freeze-Dried KF (BFDKF) samples}

According to the nutrition information panel (Food Safety and Standards Authority of India, 2010), every food processing operation is required to provide information on certain nutrients. Table 7 shows the proximate analyses of the KF and BFDKF powder samples.

Table 7. Proximate analysis of the raw kiwi fruit and blended freeze-dried kiwi fruit powder sample.

\begin{tabular}{|c|c|c|c|c|c|c|}
\hline $\begin{array}{c}\text { Quality } \\
\text { Parameters }\end{array}$ & 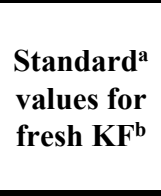 & $\begin{array}{c}\text { Fresh } \\
\text { KF } \\
\text { tested }\end{array}$ & $\begin{array}{l}\text { KF samples } \\
\text { for } \\
\text { OPODFD }^{\mathbf{c}}\end{array}$ & $\begin{array}{c}\text { KF } \\
\text { samples } \\
\text { for } \\
\text { BFDKF } \\
\text { powder }\end{array}$ & Test method & Reference(s) \\
\hline $\begin{array}{l}\text { Moisture } \\
(\mathrm{g} / 100 \mathrm{~g})\end{array}$ & $70-85$ & 85.07 & 4.27 & 3.0 & Moisture meter & Krokida et al. (1998) \\
\hline $\begin{array}{l}\text { Carbohydrate } \\
(\mathrm{g} / 100 \mathrm{~g})\end{array}$ & 14.66 & 10.89 & 87.52 & 72.17 & IS:1656-2007 & $\begin{array}{c}\text { fssai, act } 2006 \text { (Food } \\
\text { Safety and Standards } \\
\text { Authority of India, } \\
\text { 2010), Maskan } \\
\text { (2001). }\end{array}$ \\
\hline $\begin{array}{c}\text { Total Sugar } \\
\text { [Glucose \& } \\
\text { Fructose] } \\
(\mathrm{g} / 100 \mathrm{~g})\end{array}$ & 8.99 & 8.30 & 56.78 & 41.48 & $\begin{array}{l}\text { IS:6287-1985 } \\
\text { (Reaffirmed- } \\
\text { 2005) }\end{array}$ & $\begin{array}{c}\text { fssai, act } 2006 \text { (Food } \\
\text { Safety and Standards } \\
\text { Authority of India, } \\
\text { 2010), Maskan } \\
\text { (2001). }\end{array}$ \\
\hline Protein $(g / 100 g)$ & 1.14 & 1.31 & 2.82 & 5.96 & $\begin{array}{c}\text { IS:7219-1973 } \\
\text { (R.A.-2005) }\end{array}$ & $\begin{array}{c}\text { fssai, act } 2006 \text { (Food } \\
\text { Safety and Standards } \\
\text { Authority of India, } \\
\text { 2010). }\end{array}$ \\
\hline $\begin{array}{l}\text { Total Fat } \\
(\mathrm{g} / 100 \mathrm{~g})\end{array}$ & & 0.52 & 0.65 & 2.53 & $\begin{array}{c}\text { fssai LAB } \\
\text { MANUAL } 5.0\end{array}$ & $\begin{array}{c}\text { fssai, act } 2006 \text { (Food } \\
\text { Safety and Standards } \\
\text { Authority of India, } \\
\text { 2010). }\end{array}$ \\
\hline $\begin{array}{l}\text { Energy Content } \\
\quad(\mathrm{kJ} / 100 \mathrm{~g})\end{array}$ & 260 & 259.8 & 1548.64 & 1428.22 & $\begin{array}{c}\text { IS:9487-1980 } \\
\text { (R.A.-2005) }\end{array}$ & $\begin{array}{c}\text { fssai, act } 2006 \text { (Food } \\
\text { Safety and Standards } \\
\text { Authority of India, } \\
\text { 2010). }\end{array}$ \\
\hline $\begin{array}{l}\text { Sodium } \\
(\mathrm{mg} / 100 \mathrm{~g})\end{array}$ & 3 & 2.81 & 1072.04 & 969.69 & $\begin{array}{l}\text { QA.16.5.2/ } \\
\text { AOAC 19-th } \\
\text { Edition }\end{array}$ & $\begin{array}{c}\text { fssai, act } 2006 \text { (Food } \\
\text { Safety and Standards } \\
\text { Authority of India, } \\
\text { 2010). }\end{array}$ \\
\hline $\begin{array}{l}\text { Potassium } \\
(\mathrm{mg} / 100 \mathrm{~g})\end{array}$ & 312 & 312.53 & 252.02 & 953.72 & $\begin{array}{l}\text { QA.16.5.2 / } \\
\text { AOAC 19-th } \\
\text { Edition }\end{array}$ & $\begin{array}{l}\text { fssai, act } 2006 \text { (Food } \\
\text { Safety and Standards } \\
\text { Authority of India, } \\
\text { 2010), Deman (2004). }\end{array}$ \\
\hline $\begin{array}{l}\text { Vitamin A } \\
(\mu \mathrm{g} / 100 \mathrm{~g})\end{array}$ & Trace & 20.0 & 20.0 & & QA.16.5.3 & $\begin{array}{c}\text { fssai, act } 2006 \text { (Food } \\
\text { Safety and Standards } \\
\text { Authority of India, } \\
\text { 2010), Ranganna } \\
\text { (1999). }\end{array}$ \\
\hline $\begin{array}{l}\text { Vitamin C } \\
(\mathrm{mg} / 100 \mathrm{~g})\end{array}$ & 90 & 89.10 & 78.66 & 193.90 & $\begin{array}{l}\text { IS: } 5838-1970 \\
\quad(\text { RA-2005) }\end{array}$ & $\begin{array}{c}\text { fssai, act } 2006 \text { (Food } \\
\text { Safety and Standards } \\
\text { Authority of India, } \\
\text { 2010). }\end{array}$ \\
\hline
\end{tabular}

${ }^{\mathrm{a}} \mathrm{fssai}$; ${ }^{\mathrm{b}}$ formation on the nutritional value of the fresh kiwi; ${ }^{\mathrm{c}}$ Optimized osmotically dehydrated freeze-dried sample.

The authors' previous paper (Chakraborty et al., 2016) reported on the optimization of an osmotically dehydrated freeze-dried (OPODFD) kiwi sample, with which the present sample was compared. The carbohydrate and sugar contents were both reduced in the BFDKF powder since there was no solute gain (due to osmotic dehydration). Only $1 \%(\mathrm{w} / \mathrm{w})$ sugar was added during the blending operation of the sliced 
KF. Since oat flour (containing $12 \%$ protein, $w / w$ ) was used to fortify the sliced KF, the final BFDKF powder contained twice as much protein as that from the OPODFD process. For the same reason (oat flour contains $8 \% \mathrm{w} / \mathrm{w}$ total fat consisting of $1.5 \%$ saturated fatty acids, $4 \%$ MUFA and $2.5 \%$ PUFA w/w), the final BFDKF powder contained six times as much total fat as that from the OPODFD process. As already mentioned, the salt added to the sliced $\mathrm{KF}$ was in the form of iodized and low $\mathrm{Na}$ (1:1 ratio) salt, so the final product contained less sodium and more potassium than the product of the OPODFD process, which is acceptable for human health. The final powdered product was low energy, high nutritional value product, as suggested by the low energy value $(1428.22 \mathrm{~kJ}$ per $100 \mathrm{~g})$ than the product from the OPODFD process $(1548.64 \mathrm{~kJ}$ per $100 \mathrm{~g})$. One interesting finding was the maximum vitamin C (193.9 $\mathrm{mg}$ per $100 \mathrm{~g})$ retention by this process, the final product containing more vitamin $\mathrm{C}$ than the product obtained from the OPODFD process $(78.66 \mathrm{mg}$ per $100 \mathrm{~g})$. The reason for this was that in the OPODFD process, the optimized osmotic dehydration was carried out for 3 hours at $50{ }^{\circ} \mathrm{C}$, and naturally more vitamins would be lost during this process. In the present process, there was no heat treatment of the blended KF paste before freezing. Thus, more vitamin $\mathrm{C}$ was retained in the present work than in the conventional FD technique. The vitamin $\mathrm{A}$ content was not determined since the raw KF only contained trace amounts of this vitamin. Some physicochemical properties such as titratable acidity, TA, crude fibre and ash were also determined as shown in Table 8.

Table 8. Physicochemical properties of blended freeze-dried kiwi fruit (BFDKF) powder.

\begin{tabular}{|c|c|c|c|c|c|}
\hline Sample type & $\begin{array}{l}\text { Standard }{ }^{a} \text { values } \\
\text { for fresh } K^{b}\end{array}$ & $\begin{array}{c}\text { KF for } \\
\text { OPODFD } \\
\text { process }\end{array}$ & $\begin{array}{l}\text { BFDKF } \\
\text { powder }\end{array}$ & Test method & Reference(s) \\
\hline $\begin{array}{c}\text { Titratable acidity } \\
(\mathrm{g} / 100 \mathrm{~g})(\text { as malic } \\
\text { acid) }\end{array}$ & 11.64 & ----- & 5.92 & $\begin{array}{l}\text { fssai Lab } \\
\text { Manual }\end{array}$ & Deman (2004) \\
\hline Crude fibre (g/100 g) & 2.9 & ----- & 5.99 & $\begin{array}{c}\text { IS: } 10226 \\
\text { (Part I) - } 1982 \\
(\text { RA-2005) }\end{array}$ & Deman (2004) \\
\hline Total ash (g/100 g) & $0.88-1.02$ & 3.92 & 7.88 & $\begin{array}{c}\text { fssai Lab } \\
\text { Manual }\end{array}$ & $\begin{array}{l}\text { fssai, act } 2006 \text { (Food } \\
\text { Safety and Standards } \\
\text { Authority of India, } \\
\text { 2010), Fourie \& } \\
\text { Hansmann (1992) }\end{array}$ \\
\hline
\end{tabular}

${ }^{\mathrm{a}}$ fssai; ${ }^{\mathrm{b}}$ information on the nutritional value of the fresh kiwi; ${ }^{\mathrm{c}}$ Optimized osmotically dehydrated freeze-dried sample.

Since the sugar-acid ratio plays an important part or role in the flavour of the final product (Deman, 2004), the TA is a major issue for a vitamin $\mathrm{C}$ rich fruit. The raw $\mathrm{KF}$ had a TA of 0.78 milliequivalents (mEq, as malic acid) per $100 \mathrm{~g} \mathrm{KF}$ and a pH value of 3.6 (Fattahi et al., 2010). That is, the raw KF had a value for TA of $11.64 \mathrm{~g}$ (as malic acid) per $100 \mathrm{~g} \mathrm{KF}$. Thus, the final BFDKF powder was less sour than the raw KF. The sugar-acid ratio (calculated based on the total \% sugar and the $\mathrm{mEq}$ factor of malic acid $=0.067$ ) increased from 10.64 to 104.57 (almost ten times) since the total \% sugar (as glucose and fructose) increased from 8.3 to $41.48 \%$ in $\mathrm{g}$ per $100 \mathrm{~g}$. Hence, the quality of the flavour of the final product improved ten times than the raw KF. The BFDKF powder also had twice as much fibre as the raw KF. One of the beneficial effects of fibre is its bulking capacity and the increase in water holding capacity of the finished product (Deman, 2004). Thus, during consumption of the powder water may be added either directly or indirectly, and in this case, the BFDKF is more beneficial for water addition since it contains almost $6 \%$ fibre. The ash content of the final product was greater than that of the OPODFD sample since it was fortified with many ingredients that were very rich in minerals such as magnesium, calcium, sodium, potassium, etc. The structure of foods is highly affected by the moisture content (Krokida et al., 1998) of the material, so KF is very suitable for preservation by FD since it has a high moisture content $(>80 \%)$. It was found that the carbohydrate and sugar levels returned to their original levels (raw KF) after the rehydration step (Maskan, 2001). 
Moreover, Tables 7 and 8 show that the moisture content of the raw and fresh KF was reduced from $85.07 \%$ to $3 \%$ in the production of the final FD product (BFDKF powder), and the carbohydrate, total sugar, protein, fat, total ash, crude fibre, and vitamin $\mathrm{C}$ contents were increased by $563 \%, 400 \%, 355 \%, 386 \%$, $672 \%, 106 \%$, and $117 \%$ respectively. In the case of the OPODFD processed product of KF when compared to the raw and fresh KF sample, the moisture content was reduced from $85.07 \%$ to $4.27 \%$, the carbohydrate, total sugar, protein, fat, and total ash contents increased by $704 \%, 584 \%, 115 \%, 25 \%$, and 284\% respectively, and the vitamin $\mathrm{C}$ content decreased by $11.72 \%$. Thus, the present work shows that the BFDKF process was of benefit as compared to the OPODFD process since the final dried product (BFDKF) was rich in both macronutrients and micronutrients.

\subsection{Sensory evaluation}

A total of 66 participants/panelists judged the BFDKF powder on the basis of seven parameters viz. sweetness, sourness, saltiness, bitterness, flavour, texture and overall acceptability using a 9-point hedonic scale. The $\%$ of consumer acceptance and the average and total scores were calculated for the individual parameters using Equations 7, 8 and 9 respectively and the results are shown in Table 9.

Table 9. Scores awarded by 66 panelists for the individual parameters \& overall acceptability using a 9-point hedonic scale $[1=$ dislike extremely to $9=$ like extremely $]$.

\begin{tabular}{cccccccc}
\hline & Sweetness & Sourness & Saltiness & Bitterness & Flavour & Texture & $\begin{array}{c}\text { Overall } \\
\text { acceptability }\end{array}$ \\
\hline $\begin{array}{c}\text { \% of consumer } \\
\text { acceptance }\end{array}$ & 68.18 & 90.91 & 100 & 100 & 95.45 & 77.27 & 81.82 \\
\hline Average score & 5.32 & 6.11 & 6.95 & 8.82 & 7.32 & 7.11 & 6.45 \\
\hline Total score & 59.09 & 67.93 & 77.27 & 97.98 & 80.30 & 79.04 & 71.72 \\
\hline
\end{tabular}

Table 9 shows that the $\%$ of consumer acceptance was $100 \%$ for saltiness and bitterness i.e. these two parameters were well accepted by the consumers, but sweetness $(68.18 \%)$ and texture $(77.27 \%)$ were less acceptable, and sourness $(90.91 \%)$ and flavour $(95.45 \%)$ were almost satisfactory according to consumer acceptance. A total of 54 panelists out of the 66 panelists gave a score of $>5$ for overall acceptability, and hence the percentage of consumer acceptance for overall acceptability of the BFDKF powder was $81.82 \%$, as shown in Table 9. As compared with previous surveys of other food products (fruit juices, lemon juices, etc.) (Singh-Ackbarali \& Maharaj, 2014; Krasaekoopt \& Kitsawad, 2010), where the acceptance was 83.3\%, the acceptance of the BFDKF powder was very close. On the other hand, as shown in Table 9, both the average score (8.82) and the total score (97.98) were highest for the parameter of bitterness. The same Table shows that the average and total scores for sweetness and sourness were the lowest amongst the parameters (almost half the maximum level), the scores for saltiness, texture and overall acceptability were lower than those found for bitterness and the scores for flavour were satisfactory. Thus, both sweetness and sourness need to be improved in future work for the BFDKF powder to be better accepted, and the parameters of saltiness (average and total scores), flavour and texture could also be improved a bit (in the direction of a 'liked extremely' classification) for a net improvement of consumer overall acceptability.

\section{Conclusions}

A value-added kiwi fruit powder was developed at a reduced cost, and tested and found to be well accepted by all for its good taste and quality. The conversion of kiwi fruits to a powder by using a consecutive value addition of blended kiwi fruit and freeze-drying protocol reduced the drying time as well as the processing costs. The cubic steel heater designed for this purpose and the silver-coated steel plate was found to be very efficient in the drying of the frozen blended kiwi fruit. As compared to the raw kiwi fruit, the nutritional components viz. carbohydrate, total sugar, protein, fat, total ash, crude fibre and vitamin $\mathrm{C}$ of the final dry 
powder were increased by $563 \%, 400 \%, 355 \%, 386 \%, 672 \%, 106 \%$, and $117 \%$ respectively. Using a hedonic scale, the \% consumer acceptance was determined for sweetness (68.18\%), sourness $(90.91 \%)$, saltiness $(100 \%)$, bitterness $(100 \%)$, flavour (95.45\%), texture (77.27\%) and overall acceptability $(81.82 \%)$.

The higher effective moisture diffusivity and lower activation energy estimated for freeze-drying are indicative of a faster and energy saving dehydration protocol with the application of a novel cubic heater, making the kiwi dehydration process economically sustainable. Further studies may be required for the evaluation of the kiwi fruit powder on the basis of its flowability, particle size, degree of caking, porosity, cohesiveness and the quantification of its bioactive components.

\section{References}

ASTM International. (2017). Standard Guide for Serving Protocol for Sensory Evaluation of Foods and Beverages (ASTM E1871-17). West Conshohocken: ASTM International. http://dx.doi.org/10.1520/E1871-17

Barrett, D. M., Somogyi, L., \& Ramaswamy, H. (2005). Processing fruits, science and technology (2nd ed., pp. 6-196). New York: CRC Press.

Benitez, S., Soro, L., Achaerandio, I., Sepulcre, F., \& Pujola, M. (2014). Combined effect of a low permeable film and edible coatings or calcium dips on the quality of fresh-cut pineapple. Journal of Food Process Engineering, 37(2), 91-99. http://dx.doi.org/10.1111/jfpe.12063

Bezyma, L. A., \& Kutovoy, V. A. (2006). Vacuum drying and hybrid technologies. Stewart Postharvest Review, 4, 6-13.

Burmester, K., Pietsch, A., \& Eggers, R. (2011). A basic investigation on instant coffee production by vacuum belt drying. Procedia Food Science, 1, 1344-1352. http://dx.doi.org/10.1016/j.profoo.2011.09.199

Chai, T., \& Draxler, R. R. (2014). Root mean square error (RMSE) or mean absolute error (MAE)? Arguments against avoiding RMSE in the literature. Geoscientific Model Development, 7(3), 1247-1250. http://dx.doi.org/10.5194/gmd-7-1247-2014

Chakraborty, N., Chakraborty, R., \& Saha, K. A. (2016). Dehydration of Kiwi Fruit (Actinidia deliciosa) by consecutive osmotic dehydration and freeze-drying. Indian Journal of Science and Technology, 9(28), 1-8. http://dx.doi.org/10.17485/ ijst/2016/v9i28/91839

Chakraborty, R., \& Roychowdhury, D. (2013). Freeze-drying kinetics in synthesis of biological hydroxyapatite-supported catalyst. Indian Journal of Science and Technology, 6(1), 3933-3939. http://dx.doi.org/10.17485/ ijst/2013/v6i1/30567

Chin, S. K., Siew, E. S., \& Soon, W. L. (2015). Drying characteristics and quality evaluation of kiwi slices under hot air natural convective drying method. International Food Research Journal, 22(6), 2188-2195.

Deman, M. J. (2004). Principles of food chemistry (3rd ed.). New York: Springer publishers.

Dhingra, D., Michael, M., Rajput, H., \& Patil, R.T. (2012). Dietary fibre in foods: a review. Journal of Food Science and Technology, 49(3), 255-266. http://dx.doi.org/10.1007/s13197-011-0365-5

Duncan, M. (2000). Technology of biscuits, crackers and cookies (3rd ed.). Cambridge: Woodhead Publishing Limited and CRC Press LLC.

Fattahi, J., Fifaii, R., \& Babri, M. (2010). Postharvest quality of kiwifruit (Actinidia deliciosa cv. Hayward) affected by pre-storage application of salicylic acid. South Western Journal of Horticulture, Biology and Environment, 1(2), 175-186.

Food Safety and Standards Authority of India - FSSAI. (2010). Training manual for food safety regulators. Food Safety and Standards Act, 2006 (Vol. 1 - Introduction to food and food processing). New Delhi: FSSAI. Retrieved in 2016, April 1, from www.fssai.gov.in

Fourie, C. P., \& Hansmann, F. C. (1992). Nutritional benefits of kiwifruit. New Zealand Journal of Crop \& Horticulture Science, $20,449-452$.

Jayasena, V., \& Cameron, I. (2008). ${ }^{\circ}$ Brix/Acid ratio as a predictor of consumer acceptability of crimson seedless table grapes Journal of Food Quality, 31(6), 736-750. http://dx.doi.org/10.1111/j.1745-4557.2008.00231.x

Joshi, K., Sparks, P., Friedman, M., \& Ravishankar, S. (2016). Impact of plant-based antimicrobial washes on sensory properties of organic leafy greens. Food and Nutrition Sciences, 7(10), 906-919. http://dx.doi.org/10.4236/fns.2016.710090

Krasaekoopt, W., \& Kitsawad, K. (2010). Sensory characteristics and consumer acceptance of fruit juice containing probiotics beads in Thailand. AU (Assumption University of Thailand). Journal of Technology, 14(1), 33-38.

Krokida, M., Karathanos, V. T., \& Maroulis, Z. B. (1998). Effect of freeze-drying conditions on shrinkageand porosity of dehydrated agricultural products. Journal of Food Engineering, 35(4), 369-380. http://dx.doi.org/10.1016/S0260-8774(98)00031-

Lim, J. (2011). Hedonic scaling: A review of methods and theory. Journal of Food Engineering, 22, 733-747. http://dx.doi.org/10.1016/j.foodqual.2011.05.008

Martin-Diana, A. B., Rico, D., Frias, J. M., Barat, J. M., Henehan, G. T. M., \& Barry-Ryan, C. (2007). Calcium for extending the shelf life of fresh whole and minimally processed fruits and vegetables: a review. Trends in Food Science \& Technology, 18(4), 210-218. http://dx.doi.org/10.1016/j.tifs.2006.11.027 
Maskan, M. (2001). Drying, shrinkage and rehydration characteristics of kiwi fruits duringhot air and microwave drying. Elsevier Journal of Food Engineering, 48(2), 177-182. http://dx.doi.org/10.1016/S0260-8774(00)00155-2

Orsat, V., Changrue, V., \& Raghavan, G. S. V. (2006). Microwave drying of fruits and vegetables. Stewart Postharvest Review, 6, 4-9.

Parameswaran, I., \& Murthi, V. K. (2014). Comparative study on physic \& phyto-chemical analysis of Persea Americana \& Actinidia deliciosa. International Journal of Scientific and Research Publications, 4(5), 1-5.

Ranganna, S. (1999). Handbook of analysis and quality control for fruit and vegetable products (3rd ed.). New Delhi: Tata McGraw Hill publishing company Ltd.

Sagar, V. R., \& Suresh Kumar, P. (2010). Recent advances in drying and dehydration of fruit and vegetables: A Review. Journal of Food Science and Technology, 47(1), 15-26. PMid:23572596. http://dx.doi.org/10.1007/s13197-010-0010-8

Salunkhe, D. K., Bolin, H. R., \& Reddy, N. R. (1991). Storage, processing and nutritional quality of fruits and vegetables (2nd ed.). Boca Raton: CRC Press.

Singh-Ackbarali, D., \& Maharaj, R. (2014). Sensory evaluation as a tool in determining acceptability of innovative products developed by UG students in food science and technology at the University of Trinidad and Tobago. Journal of Curriculum and Teaching, 3(1), 10-27.

Singletary, K. (2012). Kiwifruit: Overview of potential health benefits. Nutrition Today, 47(3), 133-147. http://dx.doi.org/10.1097/ NT.0b013e31825744bc

Tavarini, S., Deglinnocenti, E., Removini, D., Massai, R., \& Guidi, L. (2008). Antioxidant capacity, ascorbic acid, total phenols and carotenoids changes during harvest and after cold storage of Kiwifruit. Journal of Food Chemistry, 107(1), 282-288.

Funding: None. 